\title{
Pengaruh Motivasi terhadap Kinerja Guru SMP Negeri Kecamatan Bangkinang Kota Kabupaten Kampar
}

\author{
RENI FARWITAWATI, SOUVYA FITHRIE \\ Fakultas Ekonomi Universitas Lancang Kuning \\ Jln. Yos Sudarso KM 8 Rumbai \\ Email :renifarwitawati@unilak.ac.id,souvyafithrie@unilak.ac.id
}

\begin{abstract}
This research aims to understand the the influence of motivation on the performance of employees at educational institutions at Bangkinang the district capital of Kampar. Type research which is located in public junior high schools Bangkinang the district capital of Kampar is descriptive with a quantitative approach, namely prioritise questions list as a means of data collection and data collected with this device then used as the main raw empirical analyze the condition of the existence of a purpose objektifitas research on the site of minutely. The population of this study is all all teachers in state schools Bangkinang the district capital of Kampar. The research is empirical research with using a technique purposive of sampling in the sample collection criteria teachers in state schools Bangkinang the district capital of Kampar that had been certified by the year 2016/2017. Of the population which consisted of 150 people, then meet the criteria of a samples from 80 people plus 3 respondents supporting such as 1 people the education office and 2 supervisors school. Data is collected by spreading the questionnaire 80th respondents and interview to 3 respondents supporting. Than 80 the questionnaires returned all (100\%). Based on technique analysis a correlation coefficient of 0,567, the coefficients determination 0,322 and results of the test $t$ and significance $<0.05$ then the researcher judging and inferring that is the motivation of the performance of teachers.
\end{abstract}

Keywords: Motivation, employee performance, Educational Institutions

Perkembangan zaman yang semakin maju menuntut adanya Sumber Daya Manusia (SDM) yang berkualitas. SDM yang berkualitas merupakan modal utama untuk mencapai tujuan pembangunan. Salah satu wahana untuk meningkatkan kualitas SDM tersebut adalah pendidikan. Undang-undang Nomor 20 Tahun 2003 tentang Sistem Pendidikan Nasional Bab I Pasal 1 Ayat 1 menyatakan pendidikan adalah usaha sadar dan terencana untuk mewujudkan suasana belajar dan proses pembelajaran agar peserta didik secara aktif mengembangkan potensi dirinya untuk memiliki kekuatan spiritual keagamaan, pengendalian diri, kepribadian, kecerdasan, akhlak mulia, serta keterampilan yang diperlukan dirinya, masyarakat, bangsa dan negara.

Sekolah merupakan tempat penyelenggaraan kegiatan pendidikan berlangsung. Keberhasilan sekolah tidak dapat terlepas dari peran guru sebagai pegawai diinstitusi pendidikan dalam menghasilkan SDM yang berkualitas. Pembelajaran yang berkualitas dapat diwujudkan oleh guru yang memiliki kemampuan dan motivasi yang tinggi dalam melaksanakan kewajiban. Kemampuan dan motivasi guru dalam mempersiapkan peserta didiknya melalui kegiatan belajar mengajar harus senantiasa ditingkatkan agar tujuan pendidikan dapat tercapai.

Fungsi dan tujuan pendidikan tertuang dalam Undang-undang Nomor 20 Tahun 2003 tentang Sistem Pendidikan Nasional Bab III Pasal 2 yang menyatakan pendidikan nasional berfungsi mengembangkan kemampuan dan membentuk watak serta peradaban bangsa yang bermartabat dalam rangka mencerdaskan kehidupan bangsa, bertujuan untuk berkembangnya potensi peserta didik agar menjadi manusia yang beriman dan bertakwa kepada Tuhan Yang Maha Esa, berakhlak mulia, sehat, berilmu, cakap, 
kreatif, mandiri, dan menjadi warga negara yang demokratis serta bertanggung jawab.

Sesuai fungsi dan tujuan pendidikan yang tertuang dalam Undang-undang yang telah disebutkan, guru sebagai salah satu faktor penentu keberhasilan tujuan pendidikan dituntut memiliki kinerja yang mampu merealisasikan harapan dan keinginan semua pihak terutama masyarakat umum yang telah mempercayai sekolah dalam membina peserta didik. Guru yang memiliki kinerja baik, memenuhi beberapa kompetensi seperti yang tercantum dalam Undang-undang Nomor 14 Tahun 2005 tentang Guru dan Dosen Bab IV Pasal 10 Ayat 1 yang menyatakan kompetensi guru sebagaimana dimaksud dalam Pasal 8 meliputi kompetensi pedagogik, kompetensi kepribadian, kompetensi sosial dan kompetensi profesional yang diperoleh melalui pendidikan profesi.

Kinerja guru SMP (Sekolah Menengah Pertama) akan berbeda dengan kinerja guru TK, SD/MI maupun SMA/MAN. Hal ini dapat terlihat pada alokasi waktu jam kerja dalam kegiatan pembelajaran di kelas, pada jenjang TK satu jam tatap muka dilaksanakan selama 30 menit, pada jenjang SD 35 menit, pada jenjang SMP 40 menit, sedangkan pada jenjang SMA selama 45 menit.

Kinerja guru dipengaruhi oleh dua faktor, yaitu: faktor kemampuan dan faktor motivasi (Sutemeister dalam Soekarno, 2009). Motivasi merupakan daya penggerak dari dalam dan di dalam subjek untuk melakukan aktivitas-aktivitas tertentu demi mencapai suatu tujuan (Sardiman, 2007:73), bila motivasi kerjanya tinggi maka akan berpengaruh pada kinerja yang tinggi dan sebaliknya jika motivasinya rendah maka akan menyebabkan kinerja yang dimiliki tersebut rendah.

Upaya untuk meningkatkan kinerja dalam rangka mencapai tujuan pendidikan bukan merupakan hal yang tidak mungkin untuk dilakukan. Salah satu upaya yang dapat dilakukan adalah dengan pemberian motivasi. Pemberian motivasi yang tepat diharapkan dapat mendorong guru untuk meningkatkan kinerjanya. Selain memacu guru untuk tidak mudah puas dengan hasil kerja yang telah dicapainya, guru juga terdorong untuk lebih produktif sehingga menghasilkan kinerja yang maksimal.

Sekolah merupakan organisasi yang terdiri dari kumpulan orang-orang yang bekerja sama untuk mencapai tujuan yang telah ditentukan. Agar kerjasama dapat berjalan baik, maka semua unsur dalam organisasi terutama sumber daya manusia harus dapat terlibat secara aktif dan memiliki dorongan untuk bersama-sama mencapai tujuan. Pimpinan dalam hal ini berperan penting untuk menggerakkan bawahan termasuk juga dirinya sendiri.

Agar sumber daya manusia dapat digerakkan dalam rangka mencapai tujuan organisasi maka perlu dipahami motivasi mereka dalam bekerja terutama untuk para guru adalah penekanan pada motivasi kerja mereka. Guru yang mempunyai motivasi kerja tinggi akan bekerja dengan keras, tekun, senang hati dan dengan dedikasi tinggi sehingga hasilnya sesuai dengan tujuan yang ingin dicapai.

Guru mendapat beberapa bentuk motivasi untuk meningkatkan kinerjanya. Salah satu bentuk dari motivasi yang diperoleh guru dari pemerintah pusat adalah tunjangan sertifikasi guru. Tunjangan sertifikasi guru yang diberikan adalah bentuk motivasi positif yang diberikan pemerintah pusat. Sedangkan motivasi positif dari pemerintah daerah adalah dengan diberikan tunjangan tambahan penghasilan. Dengan diberikan tunjangan profesi guru dan tunjangan tambahan penghasilan dari pemerintah daerah sebagai bentuk motivasi positif untuk guru, diharapkan dapat meningkatkan kinerja guru dalam meningkatkan keberhasilan pendidikan.

Kepala sekolah sebagai pimpinan top Level management di sekolah berperan penting dalam memegang kunci keberhasilan. Untuk mewujudkan harapan tersebut kepala sekolah harus kompeten. Secara umum harus memiliki pengetahuan, keterampilan, sikap, performance dan etika

p.ISSN: $2407-800 X \quad$ e.ISSN: 2541-4356 
kerja sesuai dengan tugas dan tanggung jawabnya sebagai kepala sekolah, yang diuraikan kompetensi profesionalisme, kompetensi wawasan pendidikan dan manajemen, kompetensi personal dan kompetensi sosial (Dharma, 2006: 60). Kepala sekolah juga harus memiliki jiwa kepemimpinan sesuai dengan konsep dari $\mathrm{Ki}$ Hajar Dewantara (Moeljono, 2005: 54) yaitu, "Ing ngarsa sung tuladha, ing madya mangun karsa, tut wuri handayani."

Tugas kepala sekolah sebagai manajer adalah melaksanakan fungsi-fungsi manajemen yang berupa perencanaan, pengorganisasian, pelaksanaan dan mengevaluasi kinerja guru. Untuk menyusun rencana kinerja guru, kepala sekolah melibatkan semua unsur personalia sekolah. Dengan diterapkannya manajemen sumber daya manusia oleh kepala sekolah atau dalam istilah manajemennya adalah manajer telah direspon oleh tenaga pendidik yang ada.

Dari uraian di atas maka dapat disimpulkan bahwa keberhasilan pendidikan ditentukan oleh kinerja guru sebagai salah satu pegawai di institusi pendidikan. Dalam dunia pendidikan guru memikul tugas dan tanggung jawab yang tidak ringan, selain guru mendidik pintar anak muridnya secara akal, (mengasah kecerdesan IQ Intelligence Quotient), guru juga mendidik siswanya untuk santun dalam budi pekertinya. Menjadi guru yang profesional tidak cukup dengan penguasaan materi saja, akan tetapi mampu mengayomi murid, menjadi contoh atau teladan bagi murid, selalu mendorong murid untuk berbuat lebih baik dan maju, serta menjaga kode etik guru, seperti filosofi $\mathrm{Ki}$ Hajar Dewantoro "ing ngarso sung tuladha, ing madya mangun karso, tut wuri handayani".

Kabupaten Kampar dipilih oleh peneliti menjadi tempat penelitian karena Kampar merupakan salah satu daerah di Riau yang sedang gencar menggalakkan usahausaha untuk meningkatkan kualitas pendidikan untuk mengejar daerah-daerah lain di Riau yang lebih maju dalam hal pendidikan. Hal ini dibuktikan dengan dianggarkannya dana pendidikan sebesar
25\% dari total APBD Kabupaten Kampar. Namun anggaran yang besar tidak dapat menjamin tercapainya kualitas pendidikan yang baik tanpa dukungan dari berbagai pihak yang berkecimpung dalam dunia pendidikan, khususnya guru.

Adapun jumlah sekolah menengah pertama (SMP) di wilayah Kabupaten Kampar, berdasarkan data referensi Kementerian Pendidikan dan Kebudayaan tahun 2016, sebanyak 123 SMP yang terdiri dari 96 SMP Negeri dan 27 SMP swasta. SMP Negeri dipilih sebagai objek penelitian karena guru-guru SMP Swasta masih sangat sedikit yang telah mendapatkan sertifikasi bila dibandingkan dengan guru-guru SMP Negeri.

Peneliti juga membatasi penelitiannya pada SMP Negeri yang berada di Kecamatan Bangkinang Kota yaitu SMP N 1 dan SMP N 2 Bangkinang Kota karena SMP Negeri di Kecamatan Bangkinang Kota merupakan sekolah yang banyak menerima bantuan dan menikmati berbagai fasilitas dan Negara berupa BKM (Bantuan Khusus Murid). BOMM (Bantuan Operasional Manajemen Mutu), Proyek MPMBS (Manajemen Peningkatan Mutu Berbasis Sekolah) yang kesemuanya itu dimaksudkan oleh pemerintah untuk meningkatkan kualitas guru dan siswa.

Dalam penelitian ini penulis memfokuskan diri hanya pada SMP Negeri yang berada di Kecamatan Bangkinang Kota yang akan menjadi objek penelitian yaitu SMP Negeri 1 Bangkinang Kota dan SMP Negeri 2 Bangkinang Kota. Kedua SMP ini pada dasarnya selalu berusaha meningkatkan kualitas guru-gurunya melalui program In House Training dengan mengundang pemateri yang ahli dalam bidangnya, menugaskan guru-guru untuk mengikuti berbagai pelatihan, seminar, workshop dan turut serta aktif dalam MGMP (Musyawarah Guru Mata Pelajaran) di Kabupaten Kampar.

Di Kecamatan Bangkinang Kota terdapat 6 SMP terdiri dari 2 SMP Negeri dan 4 SMP swasta. Jumlah guru SMP di Kecamatan Bangkinang Kota sebagian

p.ISSN: 2407-800X e.ISSN: 2541-4356 
besar ada di SMP N 1 dan SMP N 2 Bangkinang Kota. Jumlah guru keseluruhan SMP N 1 Bangkinang Kota pada tahun pelajaran 2015/2016 adalah 87 orang yang terdiri dari 49 orang guru yang telah tersertifikasi dan 38 orang guru yang belum disertifikasi. Adapun jumlah guru keseluruhan SMPN 2 Bangkinang Kota pada tahun pelajaran 2015/2016 adalah 63 orang yang terdiri dari 31 orang guru yang sudah disertifikasi dan 32 orang guru yang belum disertifikasi.

Berdasarkan data tersebut seharusnya kualitas pendidikan di Kampar khususnya pada jenjang SMP seharusnya meningkat seiring dengan meningkatnya kualitas guru. Optimalnya kebijakan sertifikasi guru ditujukan untuk meningkatkan kualitas guru dalam melaksanakan proses belajar-mengajar sehingga nantinya juga akan terjadi peningkatan terhadap hasil dari proses ini. Banyaknya guru yang telah mendapat sertifikasi seharusnya berbanding lurus dengan meningkatnya kualitas pembelajaran dan prestasi siswa. Karena secara teori guru yang mendapat sertifikasi adalah guru yang profesional dan guru yang profesional adalah guru yang kompeten dalam mendidik dan mengantarkan siswa untuk dapat berprestasi.

Menurut Usman (2011:250), motivasi ialah keinginan untuk berbuat sesuatu, sedangkan motif adalah kebutuhan (need), keinginan (wish), dorongan (desire) atau impuls. Motivasi merupakan keinginan yang terdapat pada seseorang individu yang merangsangnya untuk melakukan tindakantindakan atau sesuatu yang menjadi dasar atau alasan seseorang berprilaku. Motivasi secara sederhana adalah faktor- faktor yang mendorong seseorang untuk berprilaku tertentu kearah tujuan yang akan dicapainya (Jusmaliani;2011;180).

Motivasi merupakan sebuah proses psikologis melalui keinginan yang belum terpuaskan yang diarahkan kepencapaian yang belum terpuaskan yang diarahkan kepencapaian tujuan/ insentif, hal ini memperlihatkan bahwa motivasi muncul karena adanya kekurangan yang dialami individu. Kekurangan itu dapat bersifat fisiologis (kebutuhan dasar manusia), psikologis (kebutuhan akan harga diri) atau sosiologis (kebutuhan berinteraksi sosial). Kebutuhan tersebut didorong dan diarahkan untuk mengurangi kekurangan akan kebutuhan (Nuraini;2013;104).

Motivasi adalah dorongan dalam dan luar diri untuk melakukan aktivitas pekerjaan untuk mencapai tujuan, Sedangkan motivasi kerja adalah keadaan atau kondisi yang mendorong, merangsang atau menggerakkan seseorang untuk melakukan sesuatu tugas kerja yang diamanatkan padanya sehingga ia dapat mencapai tujuan organisasinya (Noor; 2013: 230).

Dari pengertian di atas dapat disimpulkan bahwa yang dimaksud motivasi kerja adalah sesuatu yang dapat menimbulkan semangat atau dorongan bekerja individu atau kelompok terhadap pekerjaan guna mencapai tujuan. Motivasi kerja pegawai adalah kondisi yang membuat pegawai mempunyai kemauan atau kebutuhan untuk mencapai tujuan tertentu melalui pelaksanaan suatu tugas. Motivasi kerja pegawai akan mensuplai energi untuk bekerja atau mengarahkan aktivitas selama bekerja, dan menyebabkan seorang pegawai mengetahui adanya tujuan yang relevan antara tujuan organisasi dengan tujuan pribadinya.

Motivasi organisasi adalah suatu keahliaan, dalam mengarahkan pegawai dan organisasi agar mau bekerja secara berhasil, sehingga keinginan para pegawai dan tujuan organisasi sekaligus tercapai. Berdasarkan tujuan yang ingin dicapai, manusia akan termotivasi oleh kebutuhan yang dimilikinya (Noor; 2013:230).

Menurut Kadarisman (2013;292), pada hakikatnya tujuan pemberian motivasi kerja kepada karyawan adalah sebagai berikut:

1. Mengubah perilaku karyawan sesuai dengan keinginan perusahaan

2. Meningkatkan gairah dan semangat kerja

3. Meningkatkan disiplin kerja

4. Meningkatkan prestasi kerja

p.ISSN: 2407-800X

e.ISSN: $2541-4356$ 
5. Meningkatkan rasa tanggung jawab

6. Meningkatkan produktivitas dan efisiensi

7. Menumbuhkan loyalitas karyawan pada perusahaan

Tujuan pemberian motivasi kerja kepada para karyawan adalah untuk mengubah perilaku karyawan sesuai dengan keinginan perusahaan. Setiap pegawai perlakukan dengan segala kelebihan, keterbatasan, dan kekurangankekurangannya. Dalam melakukan pekerjaan, seseorang pegawai berbuat atau tidak berbuat bukanlah semata-semata didorong oleh faktor-faktor ratio (pikiran), tetapi juga kadang- kadang dipengaruhi oleh faktor emosi (perasaan). Oleh sebab itu, faktorfaktor ini perlu mendapat perhatian dalam pemberian motivasi, supaya motivasi itu betul-betul menjadi tepat sasaran.

Manfaat motivasi yang utama adalah menciptakan gairah kerja, sehingga produktifitas kerja meningkat. Sementara itu, manfaat yang diperoleh karena bekerja dengan orang-orang yang termotivasi adalah pekerjaan dapat terselesaikan dengan cepat. Artinya pekerjaan diselesaikan sesuai standar yang benar dan dalam skala waktu yang sudah ditentukan. Suatu yang dikerjakan karena ada motivasi yang mendorongnya akan membuat orang senang mengerjakannya. Orang pun akan merasa dihargai atau diakui.

Menurut Ayu Putri dkk $(2014 ; 145)$ membangun motivasi pada pegawai dapat dilakukan dengan memberi penghargaan atas pencapaian pekerjaan, membuat jenjang karir yang jelas dan fair sehingga menimbulkan rasa kebanggaan pegawai terhadap pekerjaan yang dilakukannya

Motivasi menyangkut prilaku manusia dan merupakan elemen vital dalam manajemen. Dengan motivasi dapat mengusahakan supaya seseorang dapat menyelesaikan pekerjaan dengan semangat karena ingin melaksanakannya (Terry;2009;130). Memberi "reward" atau penghargaan, dan "punishment" atau hukuman oleh atasan kepada bawahan juga dapat dipandang sebagai upaya peningkatan motivasi kerja. Dipandang dari segi ini, maka motivasi dapat dibedakan menjadi dua yaitu (Notoatmodjo;2009;131):

1. Motivasi Positif (Insentif Positif)

2. Motivasi Negatif (Insentif Negatif)

Kedua jenis motivasi tesebut dapat diterapkan dalam pimpinan organisasi, dilakukan secara seimbang dan tepat agar meningkatkan semangat kerja karyawan. Motivasi positif tepat digunakan untuk motivasi jangka panjang, sedangkan insentif negatif, hanya cocok untuk meningkatkan motivasi jangka pendek saja.

\section{Menurut}

Mangkunegara $(2011 ; 100)$, terdapat beberapa prinsip dalam memotivasi kerja pegawai, yaitu:

1. Prinsip partisipasi

2. Prinsip komunikasi

3. Prinsip mengakui andil bawahan

4. Prinsip pendelegasian wewenang

5. Prinsip memberi perhatian

Teori hirarki kebutuhan Abraham $\mathrm{H}$. Maslow

Terdiri dari kebutuhan fisiologis, keamanan, sosial, penghargaan dan aktualisasi diri. kebutuhan fisiologis, keamanan, sosial merupakan kebutuhan tingkat rendah (faktor eksternal) dan kebutuhan penghargaan dan aktualisasi diri merupakan kebutuhan tingkat tinggi (faktor internal). Teori ini mengasumsikan bahwa orang berupaya memenuhi kebutuhan yang lebih pokok (psikologi) sebelum memenuhi kebutuhan yang tertinggi (aktualisasi diri).

Teori kebutuhan David McClelland

McClelland dalam T. Hani Handoko (2003) memberikan tiga tingkatan kebutuhan tentang motivasi sebagai berikut: Kebutuhan akan prestasi (need for achievement), afiliasi (need for affiliation), kekuasaan (need for power).

\section{Teori dua faktor Herzberg}

Menurut Herzberg (1966), ada dua jenis faktor yang memotivasi seseorang untuk berusaha mencapai kepuasan dan menjauhkan diri dari ketidakpuasan. Dua faktor itu disebutnya faktor higiene (faktor 
ekstrinsik) dan faktor motivator (faktor intrinsik).

1. Teori Douglas McGregor (Teori X dan Teori Y)

2. Douglas McGregor mengemukakan dua pandangan yang jelas berbeda mengenai manusia. Pada dasarnya yang satu negatif, yang ditandai sebagai Teori $\mathrm{X}$, dan yang lain positif, yang ditandai dengan Teori Y.

3. Teori Pengharapan

Dewasa ini, salah satu dari penjelasan yang paling diterima secara luas mengenai motivasi adalah teori pengharapan (ekspektasi) dari Victor Vroom. Teori ini berargumen bahwa kekuatan dari kecenderungan untuk bertindak dengan cara tertentu bergantung pada kekuatan dari kecenderungan untuk bertindak dengan cara tertentu bergantung pada kekuatan pengharapan bahwa tindakan itu akan diikuti oleh output tertentu dan tergantung pada daya tarik output itu bagi individu tersebut.

Secara etimologi, kinerja berasal dari kata prestasi kerja (performance). Sebagaimana dikemukan oleh Mangkunegara (2007) bahwa isitilah kinerja dari kata kata job performance atau actual performance (prestasi kerja atau prestasi sesungguhnya yang dicapai oleh seseorang) yaitu hasil kerja secara kualitas dan kuantitas yang dicapai oleh seorang pegawai dalam melaksanakan tugasnya sesuai dengan tanggung jawab yang diberikan padanya. Lebih lanjut Mangkunegara (2007) menyatakan bahwa pada umumnya kinerja dibedakan menjadi dua, yaitu kinerja individu dan

Hasibuan dalam Hetami $(2008 ; 70)$ menyatakan kinerja adalah suatu hasil kerja yang dicapai seseorang dalam melaksanakan tugas-tugas yang dibebankan kepadanya yang didasarkan atas kecakapan, pengalaman, kesungguhan, dan waktu. Sedangkan menurut As'ad dalam Hetami $(2008 ; 70)$ kinerja sebagai hasil yang dicapai seeorang menurut ukuran yang berlaku untuk pekerjaan yang bersangkutan. Jadi kierja berkenaan dengan hasil kerja yang dicapai oleh karyawan dalam waktu tetentu.
Nawawi (2004) menyatakan bahwa, "Kinerja adalah hasil pelaksanaan suatu pekerjaan, baik bersifat fisik/ material maupun non fisik/ non material. Menurut Simanjutak (2005), "Kinerja adalah tingkatan pencapaian hasil atas pelaksanaan tugas tertentu. Simanjuntak juga mengartikan kinerja individu sebagai tingkat pencapaian atau hasil kerja seseorang dari sasaran yang harus dicapai atau tugas yang harus dilaksanakan dalam kurun waktu tertentu". Foster dan Seeker (2001) menyatakan bahwa, "Kinerja adalah hasil yang dicapai seseorang menurut ukuran yang berlaku untuk pekerjaan yang bersangkutan.

Berdasarkan pendapat di atas berbagai macam jenis pekerjaan yang dilakukan oleh pegawai, tentunya membutuhkan kriteria yang jelas, karena masing-masing pekerjaan tentunya mempunyai standar yang berbeda-beda tentang pencapaian hasilnya. Makin rumit jenis pekerjaan, maka standar operating procedure yang ditetapkan akan menjadi syarat mutlak yang harus dipatuhi. Dari beberapa pendapat di atas, kinerja pegawai pada hakikatnya suatu hasil yang dapat dicapai oleh pegawai dalam suatu organisasi, sesuai dengan wewenang dan tanggung jawab masing-masing, dalam rangka mencapai tujuan organisasi. Kinerja memainkan peranan penting bagi peningkatan kemajuan atau perubahan kea rah yang lebih baik yaitu terhadap pengukuran fakta-fakta yang akan menghasilkan data.

Guru dan dosen sebagai pendidik, kinerja dosen adalah seperangkat perilaku yang ditunjukkan oleh dosen pada saat menjalankan tugas dan kewajibannya dalam bidang pengajaran. (Afrijal, 2015)

Kinerja dapat digambarkan sebagai fungsi proses dari respon individu terhadap ukuran kinerja yang diharapkan organisasi, yang mencakup desain kinerja, proses pemberdayaan, dan pembimbingan, serta dari sisi individu itu sendiri yang mencakup keterampilan, kemampuan dan pengetahuan. Kinerja merupakan hasil 
suatu proses perpaduan kapabilitas individu dengan sikap individu terhadap aspek pekerjaan dan organisasi.

Menurut Mangkunegara $(2007 ; 67)$ faktor-faktor yang mempengaruhi kinerja seseorang, yaitu:

1) Faktor kemampuan, secara umum kemampuan ini terbagi menjadi 2 yaitu kemampuan potensi (IQ) dan kemampuan reality (knowledge dan skill).

2) Faktor motivasi, motivasi terbentuk dari sikap karyawan dalam menghadapi situasi kerja.

Kinerja terbaik menurut Griffin dalam Sule dan Saefullah $(2005 ; 235)$. ditentukan oleh 3 faktor, yaitu:

(1) Motivasi, yaitu yang terkait dengan keinginan untuk melakukan pekerjaan,

(2) Kemampuan, yaitu kapabilitas dari tenaga kerja atau SDM untuk melakukan pekerjaan,

(3) Lingkungan pekerjaan,yaitu sumber daya dan situasi yang dibutuhkan untuk melakukan suatu pekerjaan tersebut".

Kinerja guru adalah kemampuan dan usaha guru untuk melaksanakan tugas pembelajaran sebaik-baiknya dalam perencanaan program pengajaran, pelaksanaan kegiatan pembelajaran dan evaluasi hasil pembelajaran (Utami, 2006:13). Kinerja guru yang dicapai harus berdasarkan standar kemampuan profesional selama melaksanakan kewajiban sebagai guru di sekolah.

Berdasarkan uraian di atas dapat disimpulkan bahwa kinerja atau prestasi kerja guru adalah keberhasilan guru dalam melaksanakan kegiatan belajar mengajar untuk mewujudkan sasaran, tujuan, visi dan misi yang tertuang dalam perumusan skema strategis suatu sekolah. Tugas mengajar merupakan tugas utama guru dalam seharihari di sekolah. Kita tidak bisa menyamakan kinerja guru dengan kinerja pegawai/karyawan, walaupun sama-sama berkedudukan sebagai pegawai negeri sipil.

Kinerja guru, sesuai Peraturan Pemerintah Nomor 74 tentang Guru Pasal 52 ayat (2) menyatakan bahwa beban kerja guru paling sedikit memenuhi 24 (dua puluh empat) jam tatap muka dan paling banyak 40 (empat puluh) jam tatap muka dalam 1 (satu) minggu pada satu atau lebih satuan pendidikan yang memiliki izin pendirian dari Pemerintah atau Pemerintah Daerah. Alokasi waktu tatap muka pada jenjang SMP selama 40 menit. Sedangkan sesuai dengan Permendiknas Nomor 41 tahun 2007 tentang Standar Proses Untuk Satuan Pendidikan Dasar Dan Menengah, menyatakan bahwa jumlah jam tatap muka di SMP dilakukan dengan menata/ merencanakan jumlah peserta didik per rombongan belajar sebanyak 32 peserta didik/ kelas.

Berkaitan dengan kinerja guru dalam melaksanakan kegiatan belajar mengajar dan tugas keprofesionalan guru dalam Undang-Undang Republik Indonesia Nomor 14 Tahun 2005 pasal 20 (a) Tentang Guru dan Dosen ditegaskan bahwa guru memiliki tugas keprofesionalan dalam melaksanakan kegiatan belajar mengajar yaitu merencanakan pembelajaran, melaksanakan proses pembelajaran yang bermutu, serta menilai dan mengevaluasi hasil pembelajaran.

Untuk mengetahui kinerja guru maka diperlukan standar kinerja untuk dijadikan acuan dalam mengadakan penilaian, yaitu membandingkan apa yang dicapai dengan apa yang diharapkan. Standar kinerja dapat dijadikan patokan dalam mengadakan pertanggungjawaban terhadap apa yang telah dilaksanakan.

Kinerja guru mempunyai spesifikasi tertentu. Kinerja guru dapat dilihat dan diukur berdasarkan spesifikasi/kriteria kompetensi yang harus dimiliki oleh setiap guru. Berkaitan dengan kinerja guru, wujud perilaku yang dimaksud adalah kegiatan guru dalam proses pembelajaran yaitu bagaimana kemampuan seorang guru dalam merencanakan pembelajaran, melaksanakan kegiatan pembelajaran, dan menilai hasil belajar.

Indikator kinerja merupakan aspekaspek yang menjadi ukuran tolak ukur dalam menilai kinerja. Menurut John Miner dalam Sudarmanto (2009; 
mengemukakan 4 dimensi yang dapat dijadikan sebagai tolak ukur dalam menilai kinerja secara umum, yaitu;

1) Kualitas, yaitu: tingkat kesalahan, kerusakan, kecermatan.

2) Kuantitas, yaitu jumlah pekerjaan yang dihasilkan.

3) Penggunaan waktu dalam kerja, yaitu tingkat ketidakhadiran, keterlambatan, waktu kerja efektif/jam kerja hilang.

4) Kerja sama dengan orang lain dalam bekerja.

Dari berbagai pendapat dapat disimpulkan bahwa indikator penilaian kinerja sangat beragam tergantung dari aspek tertentu yang diukur misalnya kinerja individunya, kinerja hasilnya, kinerja prosesnya dan cara pengukurannya.

Berkenaan dengan kepentingan penilaian terhadap kinerja guru. Georgia Departemen of Education telah mengembangkan teacher performance assessment instrument yang kemudian dimodifikasi oleh Depdiknas menjadi Alat Penilaian Kemampuan Guru (APKG). Alat penilaian kemampuan guru, meliputi: (1) rencana pembelajaran (teaching plans and materials) atau disebut dengan RPP (Rencana Pelaksanaan Pembelajaran), (2) prosedur pembelajaran (classroom procedure), dan (3) hubungan antar pribadi (interpersonal skill).

Ketiga indikator penilaian kinerja guru yang diterbitkan oleh Depdiknas sebagai Alat Penilaian Kemampuan Guru (APKG) telah dituangkan secara rinci dalam Permendiknas Nomor 41 Tahun 2007 tentang Standar Proses yang berisi kriteria minimal pelaksanaan proses pembelajaran yaitu perencanaan, pelaksanaan, penilaian dan pengawasan proses pembelajaran, sehingga dalam penelitian ini penulis menggunakan Standar Proses sesuai Permendiknas Nomor 41 Tahun 2007 sebagai tinjauan untuk mengetahui kinerja guru.

Mangkunegara (2005:67) menyatakan faktor yang mempengaruhi kinerja adalah faktor kemampuan dan faktor motivasi. Seorang karyawan yang bekerja dalam suatu perusahaan, tentu dilandasi dengan keinginan untuk mencukupi kebutuhannya, baik kebutuhan akan sandang, pangan, papan. Selain itu, mereka juga memerlukan pemenuhan kebutuhan akan rasa aman dalam bekerja, mendapatkan pengakuan atas pekerjaan yang dilakukan, serta dapat mengaktualisasikan diri dalam lingkungan kerja. Dengan motivasi yang dimiliki oleh para karyawan tersebut, ia akan bekerja dengan seoptimal mungkin untuk mencapai kinerja dalam melaksanakan pekerjaannnya dan tidak semata-mata untuk memenuhi kebutuhan saja. Begitu besar pengaruh motivasi dalam suatu pekerjaan, sehingga menjadi salah satu faktor yang harus di pertimbangkan oleh suatu organisasi untuk bisa membuat karyawan termotivasi dengan pekerjaannya. Suatu pekerjaan yang tidak dilandasi oleh motivasi kerja,maka akan menimbulkan hasil kerja yang tidak maksimal.

Dengan demikian kinerja guru sebagai salah satu pegawai di institusi pendidikan sangat menentukan keberhasilan proses belajar mengajar yang efektif dan efisien sehingga tujuan pendidikan dapat tercapai dan terwujud dari prestasi siswa yang baik. Hubungan motivasi dengan kinerja guru dapat dinyatakan sebagai

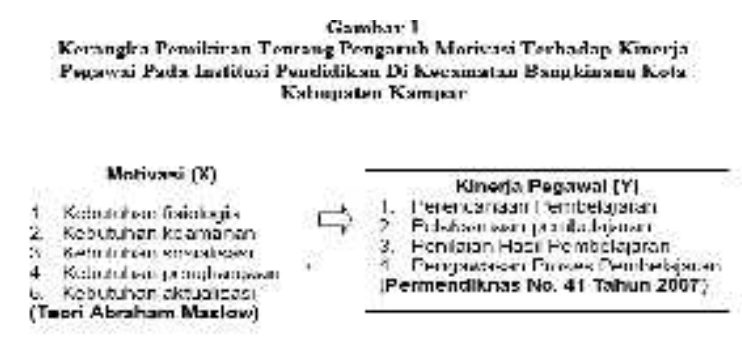

berikut:

\section{METODE}

Jenis penelitian survey, dengan guru di SMP Negeri Kecamatan Bangkinang Kota Kabupaten Kampar pada tahun pelajaran 2016/2017 yang sudah tersertifikasi berjumlah 86 orang yaitu 49 orang guru SMPN 1 Bangkinang Kota dan 31 orang guru di SMPN 2 Bangkinang Kota. Data dikumpulkan dengan kuesioner,

p.ISSN: 2407-800X

e.ISSN: $2541-4356$ 
Metode analisa data dalam penelitian ini menggunakan analisis kuantitatif.

\section{HASIL}

Hasil analisis data dengan bantuan komputer software SPSS menunjukkan bahwa variabel motivasi berpengaruh terhadap kinerja guru (karena $\mathrm{p}<0,05$ ). Selanjutnya uji kenormalan data menunjukkan semua variabel terdistribusi normal. Berikut adalah tabel hasil anaisis regresi linier sederhana.

Analisis Regresi Linier Sederhana

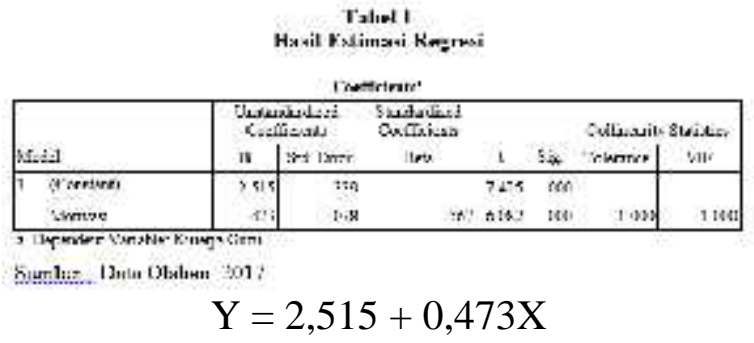

Dari persamaan tersebut dapat dijelaskan bahwa:

1. Variabel motivasi mempunyai arah koefisien yang bertanda positif terhadap kinerja guru.

2. Nilai $\mathrm{a}=2,515$ menunjukkan bahwa jika motivasi 0 (nol) maka tingkat kinerja guru adalah sebesar 2,515.

3. Nilai $\mathrm{b}=0,473$ menunjukkan jika motivasi naik $1 \%$ maka variabel kinerja guru akan mengalami peningkatan sebesar 0,473.

Nilai koefisien determinasi ditentukan dengan nilai adjusted $R$ square sebagaimana dapat dilihat pada tabel 2

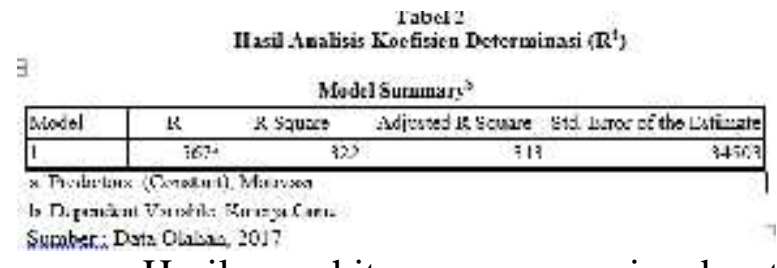

Hasil perhitungan regresi dapat diketahui bahwa $\mathrm{R}=0,567$ berarti terdapat hubungan antara motivasi (X) terhadap kinerja pegawai (Y) sebesar $56,7 \%$. Artinya hubungan antar variabel cukup erat.

Koefisien determinasi (adjusted $R^{2}$ ) yang diperoleh sebesar 0,322 . Hal ini berarti $32,2 \%$ variasi variabel kinerja guru dapat

Jurnal Daya Saing dijelaskan oleh variabel motivasi, sedangkan sisanya sebesar $67,8 \%$ diterangkan oleh variabel lain yang tidak diajukan dalam penelitian ini.

Dari tabel 1 terlihat bahwa hasil pengujian statistik secara parsial motivasi menunjukkan nilai $\mathrm{t}$ hitung sebesar 6,082 dengan taraf signifikansi 0,000. Taraf signifikansi tersebut lebih kecil dari 0,05, yang berarti bahwa motivasi berpengaruh terhadap kinerja guru SMP Negeri di Kecamatan Bangkinang Kota Kabupaten Kampar.

Berdasarkan hasil analisa menunjukkan bahwa motivasi berpengaruh positif dan signifikan terhadap kinerja pegawai pada institusi pendidikan. Maka dapat disimpulkan hasil dimensi motivasi dan kinerja di pegawai pada institusi pendidikan di Kecamatan Bangkinang Kota Kabupaten Kampar telah berjalan baik. Hasil penelitian ini sejalan dengan penelitian yang dilakukan oleh Sastriawan (2012) yang menyebutkan bahwa jika aspek-aspek motivasi atau motif pegawai dalam bekerja baik, maka secara umum kinerja pegawai yang bersangkutan akan baik. Hal ini disebabkan karena setiap pegawai memiliki motif atau motivasi yang berbeda dalam bekerja.

\section{PEMBAHASAN}

Motivasi adalah sesuatu yang timbul dari dalam diri sebagai sebuah kekuatan seseorang secara sadar untuk melakukan aktifitas yang dapat menhasilkan suatu perubahan secara nyata untuk membatu dirinya sendiri dan juga orang lain dalam menangani suatu permasalahn yang dihadapinya sehingga dapat memberikan kepuasan bagi dirinya dan juga kepada masyarakat baik itu individu maupun kelompok, semakin tinggi motivasi seseorang akan banyak menentukan terhadap kualitas perilaku yang ditampilkannya, seorang pimpinan seharusnya harus banyak memberikan motivasi kepada bawahannya sehingga mereka merasa puas dalam bekerja dan hasilnya akan terlihat secara nyata. 
Agar sumber daya manusia dapat digerakkan dalam rangka mencapai tujuan organisasi maka perlu dipahami motivasi mereka dalam bekerja terutama untuk para guru adalah penekanan pada motivasi kerja mereka. Pemberian motivasi kepala sekolah kepada guru maupun motivasi yang timbul dari diri guru sendiri untuk bekerja sambil berprestasi akan mampu mencapai kepuasan kerjanya, tercapainya kinerja organisasi yang maksimal dan tercapainya tujuan organisasi. Guru yang mempunyai motivasi kerja tinggi maka ia akan bekerja dengan keras, tekun, senang hati dan dengan dedikasi tinggi sehingga hasilnya sesuai dengan tujuan yang ingin dicapai.

Guru memiliki peran yang strategis dalam bidang pendidikan, bahkan sumber daya yang lain yang memadai sering kali kurang berarti apabila tidak disertai dengan kualitas guru yang memadai. Apabila guru yang berkualitas kurang ditunjang oleh sumber daya pendukung lain yang memadai, juga dapat mengakibatkan kurang optimal kinerjanya.

Dari uraian di atas maka dapat disimpulkan bahwa keberhasilan pendidikan ditentukan oleh kinerja guru. Dalam dunia pendidikan guru memikul tugas dan tanggung jawab yang tidak ringan, selain guru mendidik pintar anak muridnya secara akal, (mengasah kecerdesan IQ Intelligence Quotient), guru juga mendidik siswanya untuk santun dalam budi pekertinya. Menjadi guru yang profesional tidak cukup dengan penguasaan materi saja, akan tetapi mampu mengayomi murid, menjadi contoh atau teladan bagi murid, selalu mendorong murid untuk berbuat lebih baik dan maju, serta menjaga kode etik guru, seperti filosofi Ki Hajar Dewantoro "ing ngarso sung tuladha, ing madya mangun karso, tut wuri handayani".

\section{SIMPULAN}

Berdasarkan hasil penelitian dan pembahawan sebagaimana telah dijelaskan sebelumnya, dapat ditarik kesimpulan bahwa motivasi kerja secara signifikan berpengaruh terhadap kinerja pegawai pada institusi pendidikan

\section{DAFTAR RUJUKAN}

Afrijal (2015) 'Pengaruh Budaya Organisasi terhadap Kinerja Dosen PTS di Provinsi Riau (Program Studi Akuntansi Dan Manajemen)'. Pekanbaru: jurnal daya saing, pp. 128-135.

Aqib, Zainal. 2009. Menjadi Guru Profesional Berstandar Nasional. Bandung: Yrama Widya.

Arikunto, Suharsimi. 2009. Dasar-Dasar Evaluasi Pendidikan. Jakarta: BumiAksara

Astuty, Nurul Yensy, 2010. Pengaruh Kompensasi Dan Motivasi Terhadap Kinerja Guru Di SMA Negeri 2 Argamakmur Bengkulu Utara, Jurnal Kependidikan Triadik, April 2010. Vol. 13 No.1

Barnawi dan Mohammad Arifin. 2012. Kinerja Guru Profesional. Yogyakarta: Ar-Ruzz Media

Dharma, Surya. 2008. Penilaian Kinerja Guru. Jakarta: Direktorat Tenaga Kependidikan Ditjen PMTK Depdiknas.

Herlambang, Susatyo. 2014. Perilaku Organisasi. Yogyakarta: Pustaka Baru

Hubungan Antara Kepemimpinan Situasional dan Motivasi Berprestasi. Journal Guruvalah. http://www.guruvalah.tk

Mangkunegara, A. A. Anwar Prabu. 2013. Manajemen Sumber Daya Manusia Perusahaan. Bandung: Remaja Rosdakarya 
Martinis Yamin dan Maisah. Standarisasi Kinerja Guru. Jakarta: Gaung Persada Press

Murwati, Hesti, 2013. Pengaruh Sertifikasi Profesi Guru Terhadap Motivasi Kerja Dan Kinerja Guru di SMK Negeri Se-Surakarta. Jurnal Pendidikan Bisnis dan Ekonomi (BISE), Vol. 1 No. 1.

Nurchasanah. 2012. Pengaruh Persepsi Guru Tentang Kepemimpinan Kepala Sekolah, Motivasi Berprestasi Dan Kompensasi terhadap Kinerja Guru SD Negeri Di Gugus Ki Hajar Dewantara Kecamatan Sayung Kabupaten Demak. Jurnal Manajemen Pendidikan FIP IKIP PGRI Semarang.

Peraturan Pemerintah Nomor 19 Tahun 2005 Tentang Standar Nasional Pendidikan. 2008. Bandung: Diperbanyak oleh Fokusmedia

Peraturan Menteri Negara Pendayagunaan Aparatur Negara dan Reformasi Birokrasi No. 16 Tahun 2009 Tentang Jabatan Fungsional Guru dan Angka Kreditnya.

Peraturan Menteri Pendidikan Nasional No. 41 Tahun 2007 Tentang Standar Proses Untuk Satuan Pendidikan Dasar dan Menengah

Siagian, Sondang P. 2012. Teori Motivasi Dan Aplikasinya. Jakarta: Rineka Cipta
Suparno dan Sudarwati. 2014. Pengaruh Motivasi, Disisplin Kerja, Dan Kompetensi Terhadap Kinerja Pegawai Dinas Pendidikan Kabupaten Sragen. Jurnal Paradigma Vo. 12 No. 1 FebruariJuli 2014

Undang-Undang Republik Indonesia Nomor 14 Tahun 2005 tentang Guru dan Dosen. 2008. Bandung: Diperbanyak oleh Fokusmedia.

Uno, Hamzah B. 2008. Profesi Kependidikan. Jakarta: PT Bumi Aksara.

Widodo, Joko. 2007. Pengaruh Kemampuan Intelektual dan Motivasi Kerja Terhadap Kinerja Guru Mata Diklat Produktif Penjualan di SMK Bisnis dan Manajemen. Dalam Jurnal Dinamika Pendidikan Volume 2 No. 2 Hal 337361 Semarang: Universitas Negeri Semarang. 